\title{
Ventilation solution to undergroud mining site in Cao Thang mine area, Hon Gai Coal Company
}

\author{
Cuong Hong Nguyen ${ }^{1}$, Khai Cao Nguyen ${ }^{1,}$, Khai Van Le ${ }^{2}$, Thuc Van Tran ${ }^{2}$ \\ ${ }^{1}$ Hanoi University of Mining and Geology, Hanoi, Vietnam \\ 2 Vietnam National Coal - Mineral Industries Holding Corporation Limited, Hanoi, Vietnam
}

\begin{abstract}
ARTICLE INFO ABSTRACT
Article history:

Received 28 $8^{\text {th }}$ Mar. 2021

Revised $28^{\text {th }}$ June 2021

Accepted $26^{\text {th }}$ July 2021

Keywords:

Cao Thang coal mine,

Mine ventilation system,

Ventilation solutions,

Wind network audit,

Mine ventilation.

Cao Thang coal mine of Hon Gai Coal Company is currently in the implementation phase of the underground mining project at level $-50 \div$ $-160 \mathrm{~m}$. It is expected that by and after 2021, the mining coal output reaches double in 2019 (about 300,000 tons/year). On the basis of the assessing results of the current ventilation status in the mining area by auditing the wind network, when increasing the mining output according to the design, this study has calculated the current ventilation demand as a basis for analyzing, evaluating the efficiency of ventilation for the mine site at level $-50 \div-160 \mathrm{~m}$ and considering the future mining project below level $-160 \mathrm{~m}$. From there, with the available conditions such as works and equipment of the mine, the authors research and propose the most suitable solutions to complete the mine ventilation system of Cao Thang area mine. Therefore, this is a research work that not only has practical economic and technical significance but also has a long-term orientation for the development plan of Cao Thang coal mine, Hon Gai Coal Company - Vinacomin.
\end{abstract}

Copyright (C) 2021 Hanoi University of Mining and Geology. All rights reserved.

${ }^{*}$ Corresponding author

E-mail address: nguyencaokhai@humg.edu.vn

https: 10.46326/JMES.2021.62(5a).06 


\title{
Tạp chí Khoa học Kỹ thuật Mỏ - Địa chất
}

Trang điện tử: http://tapchi.humg.edu.vn

\section{Giải pháp thông gió cho khai trường mỏ than Cao Thắng, Công ty than Hòn Gai}

\author{
Nguyễn Hồng Cường ${ }^{1}$, Nguyễn Cao Khải ${ }^{1, *}$, Lê Văn Khải ${ }^{2}$, Trần Văn Thức ${ }^{2}$ \\ 1 Trường Đại học Mỏ - Địa chất, Hà Nội, Việt Nam \\ ${ }^{2}$ Tập đoàn Công nghiệp Than - Khoáng sản Việt Nam, Hà Nội, Việt Nam
}

THÔNG TIN BÀI BÁO T TÓM TẮT

\section{Quá trình:}

Nhận bài 28/03/2021

Sứa xong 28/6/2021

Chap nhận đăng 26/7/2021

Tùr khóa:

Giải pháp thông gió, Hệ thống thông gió mỏ,

Kiểm toán mạng gió,

Mỏ than Cao Thắng,

Thông gió mỏ.
Khai trường mỏ than Cao Thắng của Công ty than Hòn Gai hiện đang trong

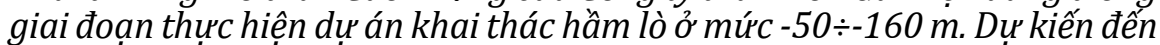
và sau năm 2021 sán lượng khai thác có thể tăng gấp đôi năm 2019 (khoảng 300.000 tấn/năm). Trên cơ sở các kết quả đánh giá hiện trạng thông gió khu khai trường mỏ bằng việc kiểm toán mạng gió, kế hoạch khi tăng sản lượng khai thác theo thiết kế, nghiên cứu này đãa tính toán nhu cầu thông gió hiện tại để làm cơ sở phân tích đánh giá hiệu quả việc thông gió cho khu mỏ, cũng nhu tính toán thông gió theo kế hoạch dự kiến tăng

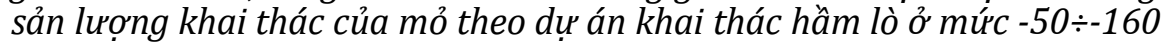
$m$, có xem xét nghiên cúu tới dư án múc dưới $-160 \mathrm{~m}$ trong tương lai. Tùu đó, với điều kiện sã̃n có nhu: các công trình, thiết bị của mó, nghiên cúu đề xuất các giải pháp phù hợp nhất giúp cho việc hoàn thiện hệ thống thông gió mỏ của khu khai trường, giải quyết việc nâng cao hiệu quả của việc thông gió, đặc biệt là việc đảm bảo an toàn mỏ, giảm giá thành thông gió, phục vu tốt kế hoạch sản xuất mỏ ở thời điểm hiện tại và trong giai đoạn tương lai khi mỏ phải tăng sản lương cùng với việc khai thác xuống mức sâu hơn theo nhu kế hoạch thực hiên dự án đã được phê duyệt. Chính vì vậy, đây là một công trình nghiên cứu không nhũng cóý nghĩa về kinh tếkỹ thuật hiện tại mà còn mang tính chất định hướng lâu dài cho kế hoạch phát triển mỏ than Cao Thắng, Công ty than Hòn Gai - TKV.

C 2021 Trường Đại học Mỏ - Địa chất. Tất cả các quyền được bảo đảm.

\section{Mở đầu}

Khai trường mỏ than Cao Thắng thuộc Công ty than Hòn Gai - TKV đang thực hiện theo dự án

*Tác giả liên hệ

E - mail: nguyencaokhai@humg.edu.vn DOI: $10.46326 / J M E S .2021 .62(5 a) .06$ khai thác "Duy trì, cải tạo và mở rộng nâng công suất khai thác hầm lò khu mỏ Cái Đá - Khoáng sàng Suối Lại - Xí nghiệp than Cao Thắng", khai thác từ mức -50 - 160 m đã được phê duyệt và đầu tư với công suất thiết kế 300.000 tấn/năm và hiện nay mỏ đang khai thác với sản lượng khoảng 150.000 tấn/năm. Năm 2019 khu mỏ đã đưa 2 lò chợ vào khai thác với 3 gương lò đào. Công tác thông gió mỏ được duy trì ổn định bằng 2 trạm quạt gió 
chính loại FBDCZ-4-No13/2x22 kW đặt ở 2 cửa lò các mức $+29 \mathrm{~m}$ và $+20 \mathrm{~m}$ để thông gió hút cho khu mỏ (Hình 1). Sơ đồ mạng gió mỏ ở khu vực khai thác được cấu trúc từ các đường lò với 2 lò chợ hoạt động và 3 gương lò chuẩn bị (Hình 2). Nhìn chung, đây là mạng gió tương đối đơn giản. Khu mỏ gồm 3 vỉa: V9, V10 và V11. Chi tiết mạng gió mỏ như sau (Phòng Thông gió, 2019a):

\section{* Nhánh I (Khu vực cánh Đông vỉa 9 và vỉa 11)}

Khu vực này được thông gió theo sơ đồ: gió sạch từ cửa lò giếng chính $+18 /-160 m$ đến lò nối mức $-50 \mathrm{~m}$ và qua lò xuyên vỉa $-50 \mathrm{~m}$ để qua các đường lò thuộc khu vực vỉa V9 và V11; gió bẩn tập trung về qua thượng thông gió $+0 /+20$ m ra ngoài.

\section{* Khu II (Khu vực cánh Tây vỉa 10 và viar11)}

Khu vực này được thông gió theo sơ đồ: gió sạch vào từ cửa lò giếng chính mức $+18 /-160 \mathrm{~m}$ đến lò xuyên vỉa mức $-160 \mathrm{~m}$, đi qua lò thượng $-160 /-120$ m vỉa 10 , qua lò dọc vỉa vách mức -100 $\mathrm{m}$ rồi vào thông gió cho lò chợ mức $-100 \mathrm{~m}$; gió thải qua lò dọc vỉa trụ mức $-100 \mathrm{~m}$ vỉa 11 , rồi qua lò thượng mức $-100 /-50 \mathrm{~m}$ vỉa 10 và qua lò thượng mức $-50 /+0 \mathrm{~m}$ để qua thượng $+0 /+29 \mathrm{~m}$ ra ngoài trời.

\section{* Các gương lò đào}

Các gương lò đào sử dụng quạt cục bộ kết hợp ống gió vải, đặt độc lập trên luồng gió sạch theo quy định. Theo kế hoạch đến cuối năm 2020 khu khai trường sẽ huy động thêm 2 lò chợ (LC) thuộc vỉa 10 (V10) vào hoạt động để đáp ứng sản lượng khai thác. Việc tăng sản lượng khai thác của mỏ dẫn đến thay đổi sơ đồ thông gió mỏ (mạng gió mỏ). Việc đánh giá hiện trạng thông gió mỏ của khu vực sẽ là cần thiết để có thể đánh giá tổng quan và đưa ra định hướng thông gió mỏ trong tương lai một cách hợp lý nhất.

\section{Phương pháp nghiên cứu}

Khai trường mỏ Cao Thắng đã được chọn làm khu vực nghiên cứu trong bài báo và đã được nhóm tác giả áp dụng các phương pháp thực địa và lý thuyết để đánh giá kiểm toán chi tiết về hiện trạng hệ thống thông gió mỏ. Việc nghiên cứu hoàn thiện hệ thống thông gió mỏ hầm lò là một công việc được thực hiện thường xuyên thậm chí hàng năm ở các mỏ hầm lò trên thế giới (A. J. H. Nel và nnk., 2018; Babak G. A. và nnk., 1982). Chính vì vậy, các phương pháp mà nhóm tác giả áp dụng ở đây là những phương pháp có cơ sở khoa học và thực tiễn.

Việc đồng thời tiến hành kiểm tra hiện trạng và tính toán yêu cầu thông gió theo kế hoạch để nghiên cứu đưa ra các giải pháp phù hợp đảm bảo an toàn sẽ mang lại hiệu quả cho mỏ than Cao Thắng, Công ty than Hòn Gai - TKV.

\section{3. Đánh giá hiện trạng thông gió khu vực mỏ Cao Thắng}

\subsection{Tính toán thông gió khu mỏ}

\section{* Lưu lượng gió mỏ}

Lưu lượng gió chung cho mỏ được tính theo công thức sau (Trần Xuân Hà và nnk., 2014):

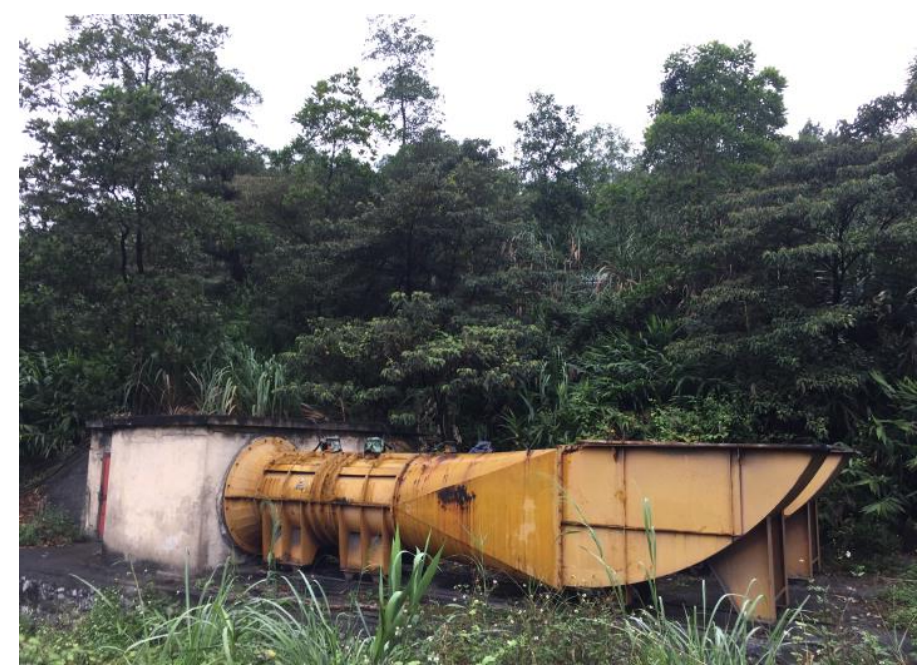

Hình 1. Hình dáng trạm quạt gió chính khu vực mỏ Cao Thắng. 


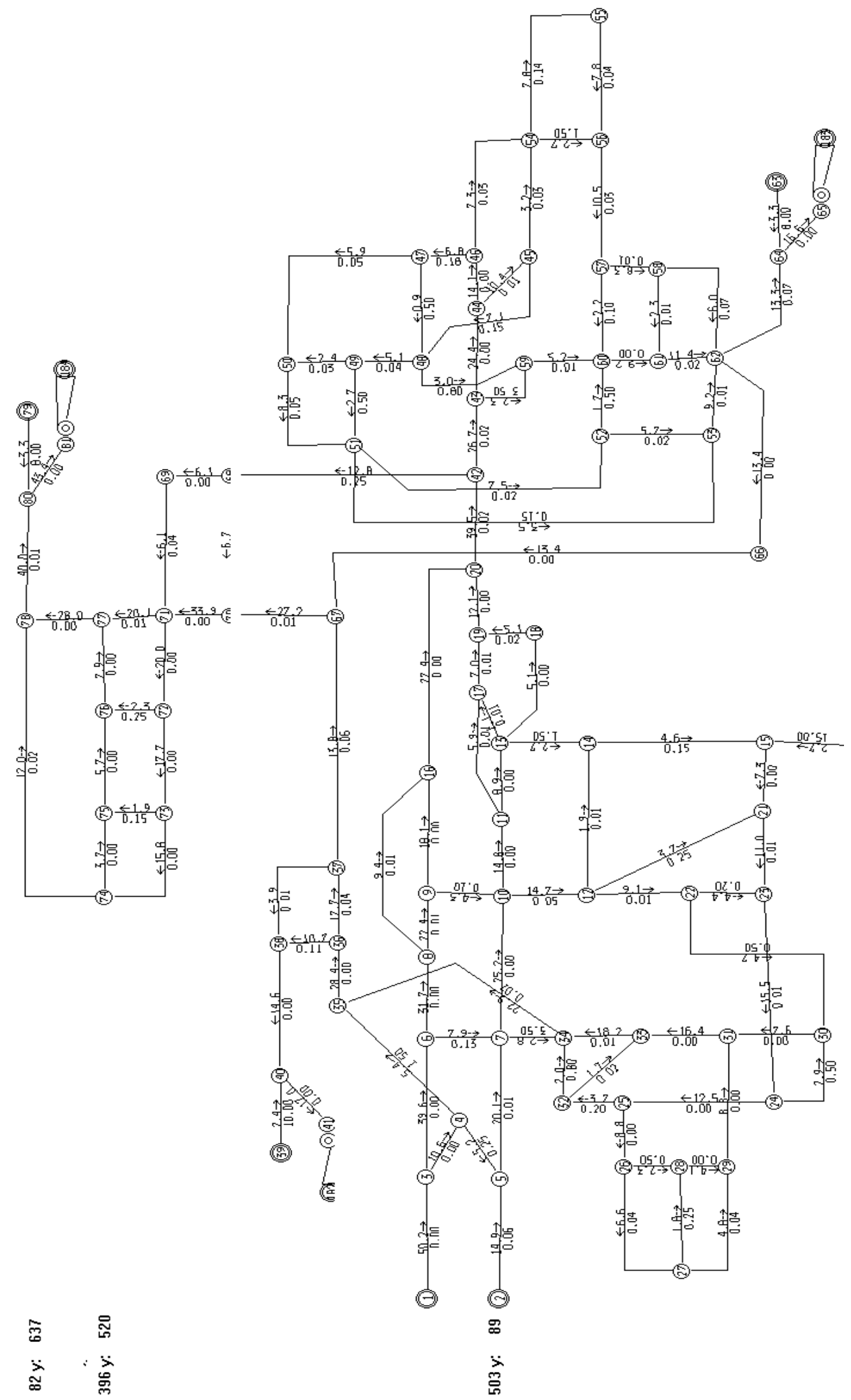

Hình 2. Sơ đồ thông gió khu mỏ Cao Thắng, Công ty than Hòn Gai - TKV. 


$$
Q_{m}=1,1\left(K_{s l} Q_{k t}+\Sigma Q_{c b}+\Sigma Q_{h t}+\Sigma Q_{r m}\right) ; m^{3} / s
$$

Trong đó: 1,1 - hệ số kể đến sự phân phối gió không đều trong các luồng gió; $K_{S l}$ - hệ số tính đến sự tăng sản lượng của lò chợ, chọn $K_{k s}=1,1 ; \mathrm{Q}_{\mathrm{rg}}$ tổng lưu lượng gió rò trong $\mathrm{mỏ}, \mathrm{m}^{3} / \mathrm{s} ; \Sigma Q_{l c}$ - tổng lưu lượng gió cần thiết cho gương lò chợ, $\mathrm{m}^{3} / \mathrm{s}$; $\Sigma Q_{c b}$ - tổng lưu lượng gió cần thiết cho gương lò đào, $\mathrm{m}^{3} / \mathrm{s} ; \Sigma Q_{h t}$ - tổng lưu lượng gió cần thiết cho hầm trạm, $\mathrm{m}^{3} / \mathrm{s}$.

Kết quả tính toán lưu lượng gió cho khu mỏ như sau:

$$
Q_{m}=1,1(1,1 \times 7,2+8,4+3,9+11,87)=35,3 \mathrm{~m}^{3} / \mathrm{s}
$$

Do khu mỏ có 2 trạm quạt gió chính, nên phân phối gió về 2 trạm quạt như sau:

- Trạm quạt 1: cửa lò mức +20 m (FBDCZ-4No13/2x22kW): $Q_{m 1}=17,5 \mathrm{~m}^{3} / \mathrm{s}$;

- Trạm quạt 2: cửa lò mức +29 m (FBDCZ-4No13/2x22kW): $Q_{m 2}=17,8 \mathrm{~m}^{3} / \mathrm{s}$.

\section{*Hạ áp mỏ}

- Hạ áp các luồng do quạt FBDCZ-4-No13 tại mức +20 m đảm nhiệm:

$h_{m 1}=95,51 \mathrm{~mm} \mathrm{H}_{2} \mathrm{O}$ (qua 2 lò chợ ngang nghiêng (LCNN): $L C-145$ / - 110 m vỉa 11 và $L C N N$ mức - $85 \mathrm{~m}$ vỉa 11 );

$$
h_{m 2}=93,81 \mathrm{~mm} \mathrm{H}_{2} \mathrm{O} \text {. }
$$

- Hạ áp luồng do quạt FBDCZ-4-No13 tại mức +29 m đảm nhiệm (có 01 luồng):

$$
h_{m 3}=80,33 \mathrm{~mm} \mathrm{H}_{2} \mathrm{O} \text {. }
$$

Như vậy, luồng có hạ áp $\mathrm{h}_{\mathrm{m} 1}=95,51$ mm $\mathrm{H}_{2} \mathrm{O}$ sẽ là hạ áp mỏ nhánh quạt gió tại trạm số 1 đảm nhiệm và quạt gió tại trạm số 2 đảm nhiệm sẽ là $\mathrm{h}_{\mathrm{m} 3}=80,33 \mathrm{~mm} \mathrm{H}_{2} \mathrm{O}$.

- Lưu lượng gió yêu cầu cần tạo ra đối với quạt gió chính:

Quạt 1 (mức $+20 \mathrm{~m}$ ): $\mathrm{Q}_{\mathrm{yc} 1}=19 \mathrm{~m}^{3} / \mathrm{s}$;

Quạt 2: (mức $+29 \mathrm{~m}): \mathrm{Q}_{\mathrm{yc} 2}=20 \mathrm{~m}^{3} / \mathrm{s}$. chính:

- Hạ áp yêu cầu cần tạo ra đối với quạt gió

Quạt 1 (mức $+20 \mathrm{~m}): \mathrm{h}_{\mathrm{yc} 1}=112,7 \mathrm{~mm} \mathrm{H}_{2} \mathrm{O}$;

Quạt 2 (mức $+29 \mathrm{~m}$ ): $\mathrm{h}_{\mathrm{yc} 2}=102,2 \mathrm{~mm} \mathrm{H}_{2} \mathrm{O}$.

- Kết quả tính toán xác định chế độ làm việc của các quạt gió chính như sau:

+ Quạt 1: điểm làm việc hợp lý của quạt là điểm $\mathrm{A}$ như trên Hình 3 . Với các thông số làm việc của quạt như sau: lưu lượng quạt tạo ra: $\mathrm{Q}_{\mathrm{ct} 1}=21.5$ $\mathrm{m}^{3} / \mathrm{s}$; hạ áp quạt tạo ra: $\mathrm{h}_{\mathrm{ct} 1}=131,9 \mathrm{~mm} \mathrm{H}_{2} \mathrm{O}$; góc lắp cánh của bánh công tác: $\theta=+50$; hiệu suất làm việc của quạt: $\eta=0,61$.

+ Quạt 2: điểm làm việc hợp lý của quạt là điểm $B$ như trên Hình 4 . Với các thông số làm việc của quạt như sau: lưu lượng quạt tạo ra: $\mathrm{Q}_{\mathrm{ct} 2}=20,0$ $\mathrm{m}^{3} / \mathrm{s}$; hạ áp quạt tạo ra: $\mathrm{h}_{\mathrm{ct} 2}=106,8 \mathrm{~mm} \mathrm{H}_{2} \mathrm{O}$; góc lắp cánh của bánh công tác: $\theta=+50$; hiệu suất làm việc của quạt: $\eta=0,62$.

\section{* Chế độ làm việc của các quạt gió chính}

- Về lưu lượng gió yêu cầu quạt cần tạo ra đối với quạt gió chính:

Quạt 1 (mức $+20 \mathrm{~m}$ ): $\mathrm{Q}_{\mathrm{yc} 1}=19 \mathrm{~m}^{3} / \mathrm{s}$;

Quạt 2: $($ mức $+29 \mathrm{~m}): \mathrm{Q}_{\mathrm{yc} 2}=20 \mathrm{~m}^{3} / \mathrm{s}$.

- Về hạ áp yêu cầu quạt cần tạo ra đối với quạt gió chính:

Quạt 1 (mức $+20 \mathrm{~m}$ ): $\mathrm{h}_{\mathrm{yc} 1}=112,7 \mathrm{~mm} \mathrm{H}_{2} \mathrm{O}$;

Quạt 2 (mức $+29 \mathrm{~m}$ ): $\mathrm{h}_{\mathrm{yc} 2}=102,2 \mathrm{~mm} \mathrm{H}_{2} \mathrm{O}$.

- Kết quả tính toán xác định chế độ làm việc của các quạt gió chính như sau:

+ Quạt 1: điểm làm việc hợp lý của quạt là điểm A như trên Hình 3 . Với các thông số làm việc của quạt như sau: lưu lượng quạt tạo ra: $\mathrm{Q}_{\mathrm{ct} 1}=21.5$ $\mathrm{m}^{3} / \mathrm{s}$; hạ áp quạt tạo ra: $\mathrm{h}_{\mathrm{ct} 1}=131,9 \mathrm{~mm} \mathrm{H}_{2} \mathrm{O}$; góc lắp cánh của bánh công tác: $\theta=+50$; hiệu suất làm việc của quạt: $\eta=0,61$.

+ Quạt 2: điểm làm việc hợp lý của quạt là điểm $B$ như trên Hình 4 . Với các thông số làm việc của quạt như sau: lưu lượng quạt tạo ra: $\mathrm{Q}_{\mathrm{ct} 2}=20,0$ m³/s; hạ áp quạt tạo ra: $\mathrm{h}_{\mathrm{ct} 2}=106,8 \mathrm{~mm} \mathrm{H}_{2} \mathrm{O}$; góc lắp cánh của bánh công tác: $\theta=+50$; hiệu suất làm việc của quạt: $\eta=0,62$.

\subsection{Hiện trạng thông gió khu mỏ}

\section{* So đồ mạng gió}

Khai trường khu vực mỏ Cao Thắng có sơ đồ mạng gió tương đối đơn giản, các trạm quạt gió có vị trí lắp đặt phù hợp với đặc điểm mạng gió. Tuy nhiên, do sử dụng 2 trạm quạt gió chính để thông gió, nên việc điều chỉnh và quản lý thông gió cũng không đơn giản.

\section{* Phương pháp thông gió}

Phương pháp thông gió chung cho mỏ đang sử dụng là phương pháp thông gió hút. Đây là phương pháp thông gió hợp lý cho mỏ, tuy nhiên khu vực vỉa V11 có trạm quạt ở cửa lò mức $+29 \mathrm{~m}$ phục vụ thông gió cho mạng đường lò tương đối phức tạp, do có nhiều nhánh nối chéo.

* Chất lượng thông gió cho các lò chơ’ 


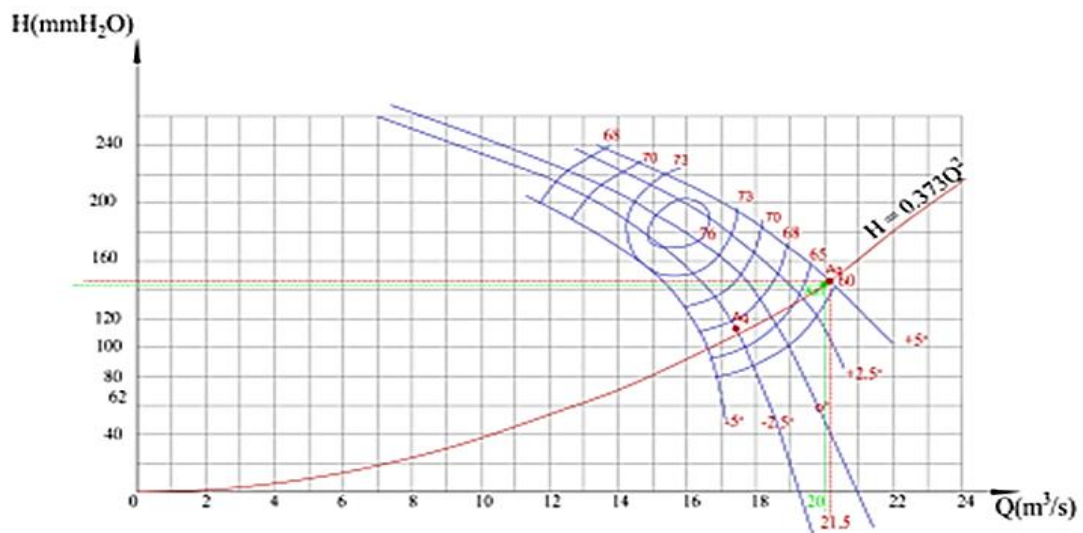

Hình 3. Đồ thị xác định chế độ công tác của quạt gió FBDCZ - 4 - No13/2x22kW tại cưa lò múc +20 m.

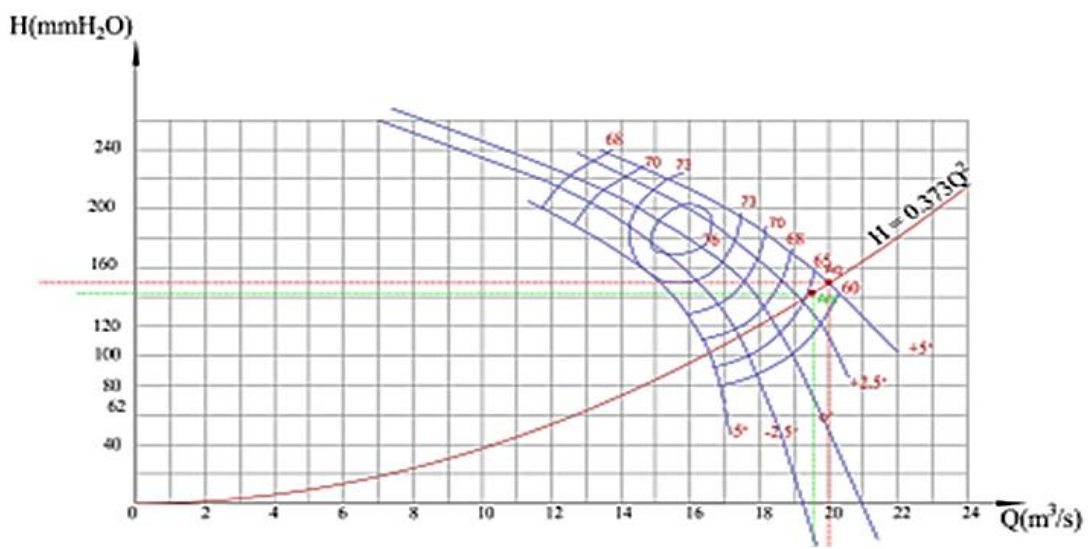

Hình 4. Đồ thị xác định chế độ công tác của quạt gió FBDCZ - 4 - No13/2x22kW tại cứa lò mức +29 m.

Để đảm bảo về lượng gió cần cung cấp, mặt khác hàm lượng các chất khí độc hoặc có hại $\left(\mathrm{CO}_{2}\right.$ và $\mathrm{CH}_{4}$ ) đều nằm dưới giới hạn cho phép và đều dao động $0,2 \div 0,3 \%$ đối với khí $\mathrm{CO}_{2}$, còn khí $\mathrm{CH}_{4}=$ 0 . Về mặt điều kiện vi khí hậu thì chất lượng thông gió đảm bảo (nhiệt độ đều là $28^{\circ} \mathrm{C}$; tốc độ gió 1,5 $\mathrm{m} / \mathrm{s}$ đối với lò chợ dài mức $-145 /-110 \mathrm{~m}$ vỉa 11 và 0,81 m/s đối với LCNN mức -85 m vỉa 11; độ ẩm tương ứng là $85 \%$ và $60 \%$ ), tuy nhiên độ ẩm tại lò chợ mức $-145 /-110 \mathrm{~m}$ vỉa 11 còn hơi cao. Nhìn chung điều kiện vi khí hậu ở lò chợ là đảm bảo dễ chịu.

\section{* Chất lượng thông gió các gương lò chuẩn bị}

Tương tự như ở lò chợ, chất lượng thông gió cho các gương lò đào mới cơ bản đảm bảo về lượng gió và khả năng hòa loãng các chất khí độc, khí nổ $\left(\mathrm{CO}_{2}\right.$ dao động $0,2 \div 0,3 \%$ và $\left.\mathrm{CH}_{4}=0\right)$. Điều kiện vi khí hậu cũng đảm bảo theo yêu cầu về nhiệt độ $\left(27 \div 28^{\circ} \mathrm{C}\right)$, tốc độ gió tối thiểu $0,25 \mathrm{~m} / \mathrm{s}$ và độ ẩm không khí $70 \div 80 \%$ ).

\section{* Chất lượng các công trình thông gió}

Nhìn chung chất lượng các công trình thông gió là đảm bảo tốt theo yêu cầu. Tuy nhiên, tại trạm quạt hiện còn thiếu cửa sổ ở rãnh quạt để kiểm tra chế độ làm việc của quạt gió (lưu lượng và hạ áp). Mặt khác, 2 cửa gió chính ở các cửa lò mức $+20 \mathrm{~m}$ và $+29 \mathrm{~m}$ là nơi đặt 2 trạm quạt gió chính chưa đảm bảo chất lượng kín gió. Vì vậy, lượng gió rò qua 2 cửa gió này vẫn đều vượt tiêu chuẩn cho phép (gió rò tương ứng 5,6 và 7,5 $\mathrm{m}^{3} / \mathrm{s}$ ). Điều này khiến cho 2 trạm quạt gió chính phải làm việc lớn hơn so với tính toán mới đủ để bù lại phần gió rò qua 2 cửa gió, chính vì vậy lượng gió đưa vào mỏ không đảm bảo yêu cầu.

\section{* Các trạm quạt gió chính}

Cả 2 trạm quạt gió chính đều có chế độ làm việc chưa đảm bảo được yêu cầu thông gió. Lưu lượng gió tạo ra để thông gió cho khu mỏ còn thiếu so với tính toán yêu cầu một lượng gió nhất định, mà nguyên nhân do lượng gió rò tại 2 cửa gió ở cửa lò mức $+20 \mathrm{~m}$ và $+29 \mathrm{~m}$ lớn. Để đảm bảo đề nghị Công ty than Hòn Gai phải gia cố cửa gió đảm bảo chất lượng theo tiêu chuẩn. 


\section{Giải pháp và định hướng công tác thông gió trong tương lai}

\subsection{Kế hoạch khai thác khu mỏ}

Sản lượng than khai thác hầm lò của Công ty than Hòn Gai - TKV năm 2019 được Tập đoàn Công nghiệp Than - Khoáng sản Việt Nam giao là: 1.700 .000 tấn/năm và năm 2020 là 1.750 .000 T/năm. Sau năm 2020 sản lượng của công ty vẫn tăng, tuy nhiên có khu vực sẽ giảm và dự kiến khu vực mỏ Cao Thắng sẽ tăng và đạt sản lượng nên khoảng 300.000 tấn/năm (Phòng Thông gió, 2019b).

Thời gian khai thác dự án từ mức $-50 \mathrm{~m}$ đến mức $-160 \mathrm{~m}$ của khu mỏ Cao Thắng dự tính đến năm 2024, sau đó sẽ tiếp nối dự án xuống sâu. Dự án xuống sâu hiện tại chưa xây dựng, tuy nhiên Công ty than Hòn Gai cũng đang tiến hành thực hiện các bước chuẩn bị để hoàn thiện các số liệu thăm dò tới mức $-500 \mathrm{~m}$ và làm các thủ tục cấp phép trước năm 2024. Dự án xuống sâu mức dưới -160 m cho thấy tiềm năng của mỏ. Hệ thống khai thác chủ yếu cho giai đoạn này là lò chợ chia lớp ngang nghiêng, và áp dụng lò chợ cột dài theo phương.

\section{2. Đề xuất các giải pháp kỹ thuật thực hiện để hoàn thiện hệ thống thông gió khu mỏ}

Trên cơ sở đánh giá hiện trạng thông gió khu vực mỏ Cao Thắng, để hoàn thiện hệ thống thông gió và nâng cao hiệu quả thông gió chung của mỏ, nhóm tác giả đề xuất Công ty than Hòn Gai - TKV cần phải áp dụng đồng bộ các giải pháp sau:

- Cần thường xuyên đo kiểm tra lưu lượng gió vào các lò chợ và gương lò chuẩn bị nhằm đảm bảo yêu cầu.

- Lò chợ mức -140/ -110 m vỉa 11 là lò chợ dài, hiện tại điều kiện thông gió đảm bảo tương đối tốt: nhiệt độ không khí nhỏ hơn $30^{\circ} \mathrm{C}$ (nhiệt độ $28^{\circ} \mathrm{C}$ ), nhưng độ ẩm không khí của lò chợ này tương đối cao ( $85 \%$ vào mùa đông). Nếu thời tiết chuyển mùa ẩm thấp hoặc sang mùa hè thì độ ẩm có thể tăng lên và khả năng sẽ là tương đối nóng bức khi độ ẩm tăng tới 90\%. Cần tính toán điều chỉnh bổ sung thêm gió sạch vào lò chợ để tạo điều kiện vi khí hậu tốt hơn.

- Đối với công tác thông gió cho các gương lò chuẩn bị cần phải đặc biệt quan tâm về năng lực các quạt gió sử dụng, chất lượng của các ống gió và chất lượng nối ống gió, để giảm mức độ tổn thất gió trên đường ống và đặc biệt giữ khoảng cách hợp lý của miệng ống gió đến gương lò nhằm đảm bảo không gian gần gương lò có tốc độ gió phù hợp, tạo điều kiện vi khí hậu tốt nhất.

- Tại các trạm quạt gió cần gia công thêm cửa kiểm tra chế độ làm việc của quạt gió chính tại rãnh quạt gió. Tại mỗi trạm quạt, cửa kiểm tra được bố trí ở rãnh quạt và cách quạt khoảng $10 \div 15 \mathrm{~m}$ với kích thước $300 \times 300 \mathrm{~mm}$. Cửa kiểm tra có cánh cửa đóng kín khi quạt làm việc, còn khi cần đo chế độ làm việc của quạt (lưu lượng và hạ áp) thì được sử dụng.

- Việc xác định hạ áp chung của mỏ thông thường được tiến hành nhờ đo đạc khảo sát thực tế, hoặc tính toán theo lý thuyết. Song các trị số này nhìn chung đều nhỏ hơn giá trị thực. Vì vậy, việc xác định chế độ làm việc hợp lý của quạt sẽ thiếu chính xác. Mặt khác, các đường đặc tính của quạt là những đường đặc tính được xây dựng trên cơ sở điều kiện sức cản chung trong điều kiện tiêu chuẩn. Cho nên, các đường đặc tính này chỉ là các đường đặc tính lý thuyết. Do vậy, để đảm bảo độ chính xác, trong quá trình vận hành trạm quạt cần định kỳ kiểm tra xây dựng các đường đặc tính thực tế của trạm quạt (có thể thực hiện định kỳ với thời gian $3 \div 5$ năm một lượt).

- Các cửa gió của khu mỏ đều được thiết kế chế tạo với tường là xây bằng gạch vữa xi măng và cánh bằng sắt, đảm bảo độ vững chắc theo yêu cầu. Tuy nhiên, các cửa gió chưa thiết kế cơ cấu đóng đảm bảo chống rò gió như chiều thông gió xuôi (các cửa gió bị bênh đế tạo khe hở rất lớn) khi tiến hành đảo chiều gió. Vì vậy, khi đảo chiều gây ra rò gió lớn (đặc biệt là các cửa gió ở các cửa lò: cửa lò mức $+20 \mathrm{~m}$ và cửa lò mức $+29 \mathrm{~m}(2$ trạm quạt FBDCZ-4-No13 ở khu mỏ Cao Thắng):

+ Các cửa gió cần gia công thanh đỡ và định hướng đế cửa ở phần nền lò, hoặc các chốt định vị các cánh cửa với phần nền đường lò, hay có thể thiết kế cánh cửa có cơ cấu cánh kép đóng theo 2 lớp tương ứng thông gió xuôi chiều và đảo chiều.

+ Khi đảo chiều cần bố trí thêm người để gác tại các cửa gió, đảm bảo các cửa gió đều được đóng chặn gió.

- Hiện mỏ đã đầu tư lắp đặt hệ thống quản lý an toàn thông gió tại trung tâm và có màn hình theo dõi và cập nhật. Vì vậy, đề xuất công ty có thể xem xét đầu tư thêm thiết bị định vị để kiểm soát và theo dõi quản lý các đoàn cán bộ thực hiện đi đo khảo sát gió và khí trong mỏ khi đảo chiều (M. Shriwas và F. Calizaya, 2018; M. A. Moridi và nnk., 
2015; A. J. H. Nel và nnk., 2018; Cao Khai Nguyen và nnk., 2019; 2020).

- Cần tổ chức xén sửa các tuyến lò thượng thông gió: lò thượng mức $-50 /-10 \mathrm{~m}$ và thượng mức $-10 /+29$ m đối với trạm quạt mức $+29 \mathrm{~m}$; lò thượng mức $-50 /+0 \mathrm{~m}$ và thượng mức $+0 /+20 \mathrm{~m}$ đối với trạm quạt mức $+20 \mathrm{~m}$ khu vực mỏ Cao Thắng đảm bảo đủ tiết diện thông gió (với tiết diện $7,4 \div 9,4 \mathrm{~m}^{2}$ ).

- Cần nâng cao công suất quạt gió chính tại trạm quạt mức $+20 \mathrm{~m}$ để đảm bảo lưu lượng gió tính toán (từ FBDCZ-4-No13 lên loại quạt có công suất BDCZ-6-No17) hoặc lắp đặt thêm trạm quạt gió loại FBDCZ-6-No17 tại cửa lò mức +60m).

\section{3. Định hướng thông gió lâu dài cho khu mỏ}

* Về phương pháp thông gió và vị trí đặt quạt

Công tác thông gió cho khu vực mỏ Cao Thắng khi tiếp tục kế hoạch khai thác dự án từ mức $-50 \div$ -160 m vẫn tiến hành như hiện nay. Cụ thể, thông gió chung cho khu mỏ sử dụng phương pháp thông gió hút, với 2 trạm quạt gió chính như hiện nay: 01 trạm quạt (loại FBDCZ-4-No13) tại cửa lò giếng thông gió mức +20 m; 01 trạm quạt (loại FBDCZ-4-N13, đặt tại cửa lò thông gió mức +29 m.

Tuy nhiên, nếu sản lượng khu vỉa 11 tăng (khu vực do trạm quạt ở mức $+20 \mathrm{~m}$ đảm nhiệm), quạt gió ở trạm quạt này đã phải làm việc ở góc lắp cánh $5^{0}$ (góc lắp cánh tối đa), nên năng lực dự trữ của quạt không còn. Khi sản lượng khai thác của khu vực đạt 300.000 tấn/năm thì lưu lượng gió cung cấp cho khu vực mỏ phải cần khoảng $55 \mathrm{~m}^{3} / \mathrm{s}$ (Nguyễn Cao Khải, 2019), vì vậy loại quạt hiện tại sẽ không đáp ứng được yêu cầu. Nhóm tác giả đề xuất 2 phương án (Babak G. A. và nnk., 1982; V.V. Sobolev, 2007; Nguyen Cao Khai và nnk., 2020):

- Phương án 1: Thay quạt cũ FBDCZ-4-No13 bằng trạm quạt mới loại quạt FBDCZ-6-No17/ 2x160 kW (hoặc loại quạt có công suất tương đương). Đặc tính kỹ thuật của quạt gió FBDCZ-IINo17/2x160 kW như trong Bảng 1.

- Phương án 2: Lắp đặt thêm trạm quạt gió mới tại cửa lò mức $+60 \mathrm{~m}$ bằng loại quạt gió FBDCZ-6-No17/2x110 kW (quạt có công suất đương đương).

* Định hướng về nhu cầu lượng gió chung cần đưa vào mỏ

Lưu lượng gió chung của mỏ cần đảm bảo được nhu cầu gió sạch như hiện tại để duy trì phần
Bảng 1. Đặc tính kỹ thuật của quạt gió chính FBDCZ-II-No17/2x160 kW.

\begin{tabular}{|c|c|c|c|}
\hline TT & Thông số & Đơn vị & Giá trị \\
\hline 1 & Đường kính bánh công tác & $\mathrm{m}$ & 1,7 \\
\hline 2 & Cấp hoạt động & cấp & 2 \\
\hline 3 & Tốc độ vòng quay & $\mathrm{v} / \mathrm{ph}$ & 980 \\
\hline 4 & Công suất & $\mathrm{kW}$ & $160 \times 2$ \\
\hline 5 & Lưu lượng gió & $\mathrm{m}^{3} / \mathrm{s}$ & $41,75 \div 81,3$ \\
\hline 6 & Hạ áp & $\mathrm{Pa}$ & $697 \div 4571$ \\
\hline
\end{tabular}

sản xuất, đồng thời khi khu vực mỏ Cao Thắng huy động thêm lò chợ để tăng sản lượng, thì nhu cầu gió khu vực sẽ tăng (nếu với sản lượng năm 2020 thì lưu lượng gió cần cho mỏ là $48,4 \mathrm{~m}^{3} / \mathrm{s}$, và như vậy 2 trạm quạt hiện nay đã làm việc hết công suất (đều đã làm việc ở góc lắp cánh cao nhất). Lúc đó cần xem xét đến phương án thay đổi loại quạt có công suất lớn hơn cho khu vực cửa lò $+20 \mathrm{~m}$, hoặc lắp đặt thêm trạm quạt gió mới tại cửa lò mức +60 $\mathrm{m}$.

* Định hướng về công tác thông gió cho lò chợ và lò chuẩn bi

Công tác thông gió cho lò chuẩn bị, lò chợ ngắn dọc vỉa phân tâng vẫn đang dùng phương pháp thông gió đẩy với các quạt gió cục bộ và ống gió có chất lượng tốt, cần tăng cường việc nâng cao ý thức của cán bộ công nhân trong việc bảo vệ thiết bị thông gió, tránh trường hợp công nhân hay chọc thủng ống gió để lấy gió sạch khi ngồi nghỉ,...

\section{Kết luận}

Việc nghiên cứu hiện trạng thông gió khu vực mỏ than Cao Thắng năm 2019 đã đánh giá được thực trạng thông gió mỏ, mức độ đảm bảo thông gió và thực trạng các công trình thiết bị thông gió. Đặc biệt đã đánh giá được năng lực của các quạt gió chính của mỏ. Hiện nay, về cơ bản công tác thông gió cho mỏ là đảm bảo yêu cầu, tuy nhiên còn một số vấn đề cần phải quan tâm thực hiện để nâng cao hiệu quả thông gió. Trong tương lai, với điều kiện khu mỏ phải tăng sản lượng khai thác theo thiết kế thì sẽ phải tăng năng lực thông gió. Chính vì vậy, công ty than Hòn Gai cần thực hiện các giải pháp như đã đề xuất, đặc biệt là phải tính toán đến phương án bổ sung hoặc thay thế trạm quạt gió chính có năng lực phù hợp mới đảm bảo thông gió an toàn. 


\section{Lời cảm ơn}

Nhóm tác giả xin chân thành cảm ơn Công ty than Hòn Gai - TKV, đã giúp đỡ cung cấp số liệu, tạo điều kiện cho các tác giả trong quá trình thực hiện bài báo này.

\section{Đóng góp của các tác giả}

Nguyễn Cao Khải hình thành ý tưởng, triển khai các nội dung và hoàn thiện bản thảo của bài báo; Nguyễn Hồng Cường, Lề Văn Khải và Trần Văn Thức triển khai thu thập thêm tài liệu tham khảo và đọc bản thảo bài báo.

\section{Tài liệu tham khảo}

A. J. H. Nel, J. C. Vosloo, M. J. Mathews, (2018). Evaluating complex mine ventilation operational changes through simulations. $J$ Energy South Africa, 29, 22-32.

Babak G. A, K. P., Bocharov, A. T., Volokhiev, (1982). Main ventilation fans for underground mining. - M.: Nedra, 296.

Cao Khai Nguyen, Van Thinh Nguyen, Van Quang Nguyen, (2019). Assessing the current status of underground mine ventilation system in Thanh Cong - Cao Thang area, Hon Gai coal company, Quang Ninh region, Vietnam. Journal of the Polish Mineral Engineering Society. 44 50.

M. Shriwas, F. Calizaya, (2018). Automation in detection of recirculation in a booster fan ventilation network. Int J Min Sci Technol, 28, 513 - 517.
M. A. Moridi, Y. Kawamura, M. Sharifzadeh, E. K. Chanda, M. Wagner, H. Jang, (2015). Development of underground mine monitoring and communication system integrated ZigBee and GIS. Int J Min Sci Technol, 25, 811 - 818.

Nguyễn Cao Khải, (2019). Nghiên cứu kiểm định mạng gió cho khu mỏ Cao Thắng, Công ty than Hòn Gai - TKV. Trung tâm Hỗ trợ phát triên KHKT, Trường Đại học Mỏ - Địa chất. 102 trang.

Nguyen Cao Khai, Nguyen Van Thinh, Nguyen Phi Hung, Dao Van Chi, Nguyen Van Quang, (2020). Current Situation and Solutions to Advanced Ventilation Efficiency in Giap Khau Coal Mine Area, Hon Gai Coal Company of Viet Nam. Journal of the Polish Mineral Engineering Society. 209-219.

Phòng Thông gió, (2019a). Kế hoạch sản xuất và thông gió Công ty than Hòn Gai năm 2019. Công ty than Hòn Gai - TKV. 53 trang.

Phòng Thông gió, (2019b). Lập kế hoạch sản xuất và thông gió Công ty than Hòn Gai năm 2020. Công ty than Hòn Gai - TKV. 52 trang.

Trần Xuân Hà, Đặng Vũ Chí, Nguyễn Cao Khải, Nguyễn Văn Thịnh, (2014). Giáo trình thông gió mỏ. Nhà xuất bản Khoa học và Kỹ thuật, Hà Nội, 357 trang.

V. V. Sobolev, (2007). Energy saving of electrical equipment for the main ventilation of mining enterprises//Mining Information and Analytical Bulletin. - Moscow. - No. 7. 391 - 395 